\title{
Occupational Stress and Coping Mechanism: Vedanta Desika's Nyasa Dasakam
}

\author{
Geetha Anand* \\ Submission: June 29, 2017; Published: July 06, 2017 \\ *Corresponding author: Geetha Anand, Research Scholar, Tamil Siddha Philosophy, India, Email: geethaa@yahoo.com
}

\section{Opinion}

The concept of stress has attracted the attention of psychologists and medical practitioners for several decades. It is a process that involves continuous interaction and adjustment between an individual and his environment, with each affecting and being affected by the other. It is a dynamic process that impacts the behavior, health and emotional state of an individual. Occupational stress or work-related stress occurs due to conditions such as work overload, monotony, role ambiguity, poor interpersonal relationships in workplace, lack of control over job demands and possibilities. While stress per se is not bad as it provides a challenging environment that would result in maximization of creativity and output,the way a person perceives it and copes with it can lead to various effects including ailments such as heart attack, hypertension, headache and other disorders.

Traditional research has shown that the effect of stress is universal but the reaction and the coping mechanisms are highly individualistic. The same situation that appeared stressful at one time may appear to be not so at a later time. One person may perceive a situation as stressful while another may consider it as a challenge that motivates him to go beyond his limitis. There are two main methods for reducing stress in the workplace. One is to alter the conditions in the workplace if it felt to be stressful by large number of individuals. If the conditions cannot be changed then educating the individual to cope with it to the best of their abilities becomes necessary. Lazarus [1] suggests that instead of focusing on a situation that causes stress the emotions generated in the adaptational struggle should be focused on to produce an effective solution as the situation perceived as stress depends on an individual.

Some of the methods of coping with stress include appraisalfocused strategies, problem- focused strategies, emotionfocused strategies and occupation-focused strategies. In the appraisal-focused strategy a person modifies the way he thinks about the stressor. He copes with it by changing his goals and values. However, this may not be possible in all situations as some of the goals such as accomplishments, targets are not open for change. Problem-focused method involves reducing the cause of the stress. If the work conditions are causing stress then the individual can modify them and reduce the stress. This is also a problem in a work environment where social interactions cannot be avoided or changed. Emotion- focused methods seem to be better solution in a situation where the environment cannot be changed. This involves addressing the emotions generated by the stressful situation. Lazaraus says that there are at least 15 emotions that can be ascribed to stress. Among the emotion-focused coping mechanisms distancing is practiced in situations where the individual is unable to bring about a change. For example,a student distances himself while waiting for the result of an examination and not worry about it as he cannot do anything about it.

Vedanta Desika, a proponent of Sri Vaishnavasa philosophy, especially the concept of satvikathyaga or peaceful surrender explains this method in the context of all the actions that one performs in one's daily life. In his composition, Nyasa Dasaka which is composed as an address to Lord Varadaraja of Kanchipuram he mentions that a discriminating individual will surrender to God his sense of self, his tendency to protect himself, his sense of being the doer of an action, the feeling that he is responsible for the action and that he is the beneficiary of the action. This surrender frees the individual from the anxiety of the result of an action. This, however, does not mean that the action is performed carelessly. It is done as a worship, as an offering, a sacrifice performed with utmost care.

A common reaction among the Hindus when an action does not bear fruit is to blame it on one's previous sins. While this attitude may give a person a reason for a failed action it plunges the individual into deep depression as one is not aware of the extent of sins one has committed. Desika requests the Lord to wipe all the sins so that he will not be in this emotional state. 
He also surrenders his idea of whether an action is good or bad. He accepts any action that he performs as divine command. This frees him of the sense of guilt or being responsible for the action. He feels that the only emotion that he is permitted to feel is that he is the servant of the Lord. Thus, he follows the divine command without questioning it. In the concluding verse Desikasays that even this act of surrendering everything to the Lord and distancing himself from the results and consequences was performed as fulfilling the Lord's will. Thus, while the devotee does not stay away from any action calling himself a recluse, he is able to perform it with detached attachment.

Desika's description of peaceful surrender is similar to Bertolt Brecht's term Verfremdungseffektwhich is roughly translated as distancing effect or alienation effect of audience from the characters in a play [2]. Brecht wanted to distance his audience from the characters and their action as this would hold them in the state of an observer who would not become involved, sympathize or identify with the characters. In that way the audience can understand the characters and analyze their actions intellectually and according to Brecht they will be "empowered to analyze and even try to change the world." Thus, the distancing effect of sacrificing the action, its ownership and its benefits through peaceful surrender helps an individual to use other coping mechanisms such as appraisal focused or problem focused methods thus avoiding the common maladies associated with occupational stress.

\section{References}

1. Richard S Lazarus (1995) Psychological Stress in the Workplace. In: Rick Crandall and Pamela L Perrewé (Eds.), Occupational Stress: A Handbook. Taylor and Francis Pub. Washington DC, USA, p: 3-14.

2. Courtesy: Wikipedia, Distancing effect.

\section{Your next submission with Juniper Publishers} will reach you the below assets

- Quality Editorial service

- Swift Peer Review

- Reprints availability

- E-prints Service

- Manuscript Podcast for convenient understanding

- Global attainment for your research

- Manuscript accessibility in different formats ( Pdf, E-pub, Full Text, Audio)

- Unceasing customer service

Track the below URL for one-step submission https://juniperpublishers.com/online-submission.php 